\title{
The top 100 most cited articles on COVID-19
}

\author{
Taylor D. Johnson BS, Surav Man Sakya BS, Judy Park Sakya BS, \\ Edwin Onkendi MBChB, David R. Hallan MD
}

\begin{abstract}
Purpose: The purpose of this study was to identify the 100 most cited publications focusing on COVID-19 to provide readers with useful historical information on current relevant research.

Methods: A search of all databases and journals accessible in Elsevier's Scopus was performed on May 13th, 2020. The document search was performed using query "COVID-19," yielding 6,693 results. A similar search was performed using Thomson Reuter's Web of Science, yielding 2,593 documents and fewer citations. The top 100 most cited papers were identified, and data were extracted. All references contained within the top 100 articles were collected. Statistical analysis was performed using R-Studio and Bibliometrix.

Results: The top 100 most cited articles were published in 50 different journals from over 25 countries. The most cited article is "Clinical features of patients infected with 2019 novel coronavirus in Wuhan, China" by Huang et al., published in The Lancet with 1184 citations. Included are a list of the top 100 most cited articles, the most cited authors, the top five journals these publications most frequently appeared in, the most contributing countries, the top institutional affiliations, and the top international collaborations of the top 100 most cited publications on COVID-19.

Conclusion: In this study, the top 100 most cited works regarding COVID-19 have been identified and analyzed. This study will serve as a historical reference for future research. This study will also provide an educational guide to facilitate effective evidence-based medical research and offer insight into the developments of COVID-19 research.
\end{abstract}

Keywords: Scientometric, Bibliometric, COVID-19, Coronavirus

\section{INTRODUCTION}

The severe acute respiratory syndrome coronavirus (SARS-CoV-2), also known as "COVID-19," has been a global tragedy in 2020. In December 2019, a series of pneumonia cases of unknown cause, clinically resembling a viral pneumonia, emerged in Wuhan, Hubei, China. Deep sequencing analysis found that SARSCoV-2 was a relative of the viruses causing severe acute respiratory syndrome (SARS) and Middle East

Corresponding author: Taylor D. Johnson

Contact Information: tjohnson11@pennstatehealth.psu.edu DOI: 10.12746/swrccc.v8i35.739 respiratory syndrome (MERS); it affects the lower respiratory tract manifesting as pneumonia in humans. ${ }^{2,3}$ The virus spreads faster than its two ancestors, but has lower mortality. ${ }^{4}$ As of June 20,2020 , there were more than 8.7 million confirmed COVID-19 cases worldwide and more than 460,000 deaths. ${ }^{5}$ The amount of published works about the virus is staggering, and medical professionals are struggling to keep up.

The aim of this study was to identify the 100 most cited publications focusing on COVID-19. Many medical specialties use bibliometrics to compile, publish, and review the most cited works within their respective fields. ${ }^{6}$ Our literature search revealed that this has not been done for COVID-19. Analyzing the current status and trends can provide a basis for relevant COVID-19 
publications, provide readers useful information about the areas of research performed, provide an educational guide to facilitate effective evidence-based medical research, and provide unique insight into the developments in COVID-19 research.

\section{Methods}

A search of all databases and journals accessible in Elsevier's Scopus was performed on May 13th, 2020. The document search was performed using query "COVID-19," yielding 6,693 results. A similar search was performed using Thomson Reuter's Web of Science, yielding 2,593 documents and fewer citations. The top 100 most cited papers from Elsevier's database were identified, and data were extracted, collected, and sorted. All references contained within the top 100 articles were collected, sorted, and counted. Statistical analysis was performed using a combination of R-Studio and Bibliometrix. ${ }^{1}$

\section{RESULTS}

\section{Citations}

All articles were published in 2020. The most cited article was "Clinical features of patients infected with 2019 novel coronavirus in Wuhan, China" by Huang C et al., published in The Lancet with 1184 citations (Table 1). ${ }^{2}$ Of the 100 most cited articles, the number of citations ranged from 32 to 1184 (Table 1).

\section{AUTHORS, COUNTRIES AND AFFILIATIONS}

A total of 720 authors contributed to these published works, with reference dates ranging from 1937 to 2020 . These articles were written by authors in various specialties, representing over 25 countries, and were published in 50 different journals. X. Li published the greatest number of the most cited articles (55). The top five countries contributing to the top 100 most cited articles were China, the United States, the United Kingdom, Germany, and Switzerland contributing 53, 17, 8, 5, and 4 articles, respectively. There were 172 reported institutional affiliations with the top 100 most cited articles. Figure 1 illustrates the institutions affiliated with greater than or equal to 10 of the 100

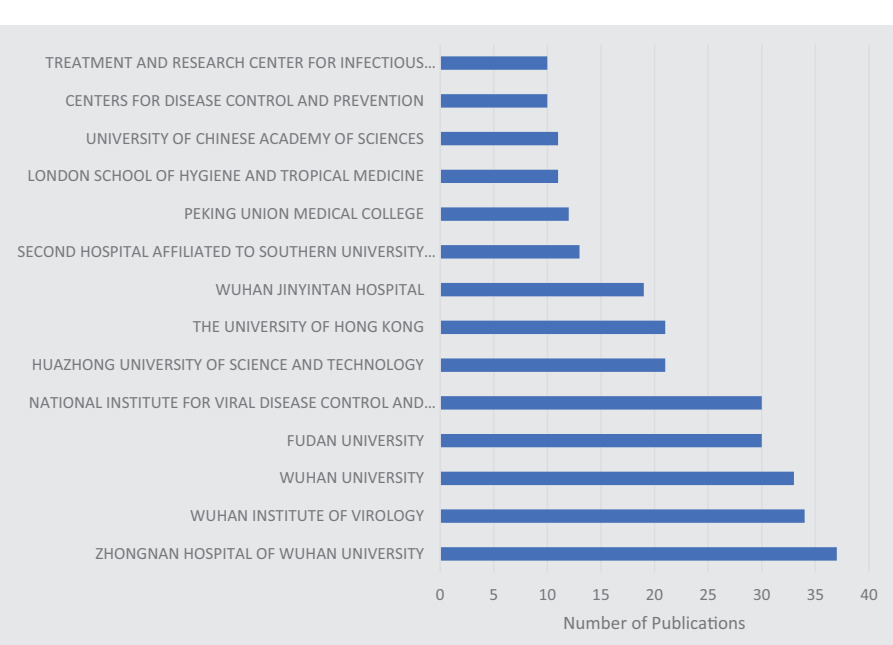

Figure 1. Top affiliations associated with greater than or equal to 10 articles.

most cited publications. Zhongnan Hospital of Wuhan University is affiliated with the most articles (37).

\section{COLLABORATIONS AND SPONSORS}

A total of 32 country to country collaborations were identified, with the most frequent collaboration in the top 100 most cited being between China and the United States. Fifty-three articles had funding sponsors. The top funding sponsors were the National Natural Science Foundation of China which sponsored 11 articles, followed by the Chinese Academy of Medical Sciences, the Chinese Academy of Sciences, and the National Basic Research Program of China, which each sponsored 10 articles.

\section{JOURNAL OF PUBLICATION}

The top five journals were (1) The Lancet with 11 publications, (2) The New England Journal of Medicine with 9, (3) Radiology with 9, (4) The Journal of the American Medical Association with 6, and (5) the Journal of Medical Virology with 4 (Figure 2).

\section{Discussion AND CONCLUSIONS}

This study sought to identify and characterize the top 100 most cited articles regarding COVID-19 to gain insight into the most influential COVID-19 articles. As the world works to understand and control this virus, it is important to understand the current research 
Table 1. The Top 100 Most Cited COVID-19 Articles

\begin{tabular}{|c|c|c|c|c|}
\hline \multicolumn{5}{|c|}{ The Top 100 Most-Cited Articles For COVID-19 } \\
\hline $\begin{array}{l}\text { Rank } \\
\#\end{array}$ & Title & Authors & Source title & $\begin{array}{c}\text { Total } \\
\text { Citations }\end{array}$ \\
\hline 1 & $\begin{array}{l}\text { Clinical features of patients infected with } 2019 \text { novel } \\
\text { coronavirus in Wuhan, China }\end{array}$ & Huang C. et al. & The Lancet & 1184 \\
\hline 2 & $\begin{array}{l}\text { A novel coronavirus from patients with pneumonia in China, } \\
2019\end{array}$ & Zhu N. et al. & $\begin{array}{l}\text { New England Journal } \\
\text { of Medicine }\end{array}$ & 705 \\
\hline 3 & $\begin{array}{l}\text { Epidemiological and clinical characteristics of } 99 \text { cases } \\
\text { of } 2019 \text { novel coronavirus pneumonia in Wuhan, China: a } \\
\text { descriptive study }\end{array}$ & Chen N. et al. & The Lancet & 641 \\
\hline 4 & Clinical characteristics of coronavirus disease 2019 in China & Guan W. et al. & $\begin{array}{l}\text { New England Journal } \\
\text { of Medicine }\end{array}$ & 570 \\
\hline 5 & $\begin{array}{l}\text { A familial cluster of pneumonia associated with the } 2019 \\
\text { novel coronavirus indicating person-to-person transmission: a } \\
\text { study of a family cluster }\end{array}$ & Chan J.F.-W. et al. & The Lancet & 451 \\
\hline 6 & $\begin{array}{l}\text { A pneumonia outbreak associated with a new coronavirus of } \\
\text { probable bat origin }\end{array}$ & Zhou P. et al. & Nature & 432 \\
\hline 7 & $\begin{array}{l}\text { Genomic characterisation and epidemiology of } 2019 \text { novel } \\
\text { coronavirus: implications for virus origins and receptor binding }\end{array}$ & Lu R. et al. & The Lancet & 379 \\
\hline 8 & $\begin{array}{l}\text { Characteristics of and Important Lessons from the } \\
\text { Coronavirus Disease } 2019 \text { (COVID-19) Outbreak in China: } \\
\text { Summary of a Report of } 72314 \text { Cases from the Chinese Center } \\
\text { for Disease Control and Prevention }\end{array}$ & Wu Z. et al. & $\begin{array}{l}\text { JAMA-Journal of the } \\
\text { American Medical } \\
\text { Association }\end{array}$ & 377 \\
\hline 9 & First case of 2019 novel coronavirus in the United States & Holshue M.L. et al. & $\begin{array}{l}\text { New England Journal } \\
\text { of Medicine }\end{array}$ & 306 \\
\hline 10 & $\begin{array}{l}\text { Clinical course and risk factors for mortality of adult } \\
\text { inpatients with COVID-19 in Wuhan, China: a retrospective } \\
\text { cohort study }\end{array}$ & Zhou F. et al. & The Lancet & 286 \\
\hline 11 & $\begin{array}{l}\text { Transmission of 2019-NCOV infection from an asymptomatic } \\
\text { contact in Germany }\end{array}$ & Rothe C. et al. & $\begin{array}{l}\text { New England Journal } \\
\text { of Medicine }\end{array}$ & 235 \\
\hline 12 & $\begin{array}{l}\text { Remdesivir and chloroquine effectively inhibit the recently } \\
\text { emerged novel coronavirus (2019-nCoV) in vitro }\end{array}$ & Wang M. et al. & Cell Research & 229 \\
\hline 13 & $\begin{array}{l}\text { Pathological findings of COVID-19 associated with acute } \\
\text { respiratory distress syndrome }\end{array}$ & Xu Z. et al. & $\begin{array}{l}\text { The Lancet } \\
\text { Respiratory Medicine }\end{array}$ & 189 \\
\hline 14 & $\begin{array}{l}\text { A new coronavirus associated with human respiratory disease } \\
\text { in China }\end{array}$ & Wu F. et al. & Nature & 168 \\
\hline 15 & $\begin{array}{l}\text { SARS-CoV-2 viral load in upper respiratory specimens of } \\
\text { infected patients }\end{array}$ & Zou L. el al. & $\begin{array}{l}\text { New England Journal } \\
\text { of Medicine }\end{array}$ & 163 \\
\hline 16 & $\begin{array}{l}\text { Cancer patients in SARS-CoV-2 infection: a nationwide } \\
\text { analysis in China }\end{array}$ & Liang W. et al. & The Lancet Oncology & 151 \\
\hline 17 & $\begin{array}{l}\text { Clinical characteristics and intrauterine vertical transmission } \\
\text { potential of COVID-19 infection in nine pregnant women: a } \\
\text { retrospective review of medical records }\end{array}$ & Chen H. et al. & The Lancet & 149 \\
\hline
\end{tabular}


Table 1. The Top 100 Most Cited COVID-19 Articles (Continued)

\begin{tabular}{|c|c|c|c|c|}
\hline \multicolumn{5}{|c|}{ The Top 100 Most-Cited Articles For COVID-19 } \\
\hline $\begin{array}{l}\text { Rank } \\
\#\end{array}$ & Title & Authors & Source title & $\begin{array}{c}\text { Total } \\
\text { Citations } \\
\end{array}$ \\
\hline 18 & $\begin{array}{l}\text { Correlation of Chest CT and RT-PCR Testing in Coronavirus } \\
\text { Disease } 2019 \text { (COVID-19) in China: A Report of } 1014 \text { Cases }\end{array}$ & Ai T. et al. & Radiology & 139 \\
\hline 19 & $\begin{array}{l}\text { The epidemiological characteristics of an outbreak of } 2019 \text { novel } \\
\text { coronavirus diseases (COVID-19) in China }\end{array}$ & $\begin{array}{l}\text { Novel Coronavirus } \\
\text { Pneumonia } \\
\text { Emergency Response } \\
\text { Epidemiology Team }\end{array}$ & $\begin{array}{l}\text { Zhonghua liu } \\
\text { xing bing xue za } \\
\text { zhi = Zhonghua } \\
\text { liuxingbingxue Zazhi }\end{array}$ & 138 \\
\hline 20 & $\begin{array}{l}\text { SARS-CoV-2 Cell Entry Depends on ACE2 and TMPRSS2 } \\
\text { and Is Blocked by a Clinically Proven Protease Inhibitor }\end{array}$ & Hoffmann M. et al. & Cell & 131 \\
\hline 21 & $\begin{array}{l}\text { Breakthrough: Chloroquine phosphate has shown apparent } \\
\text { efficacy in treatment of COVID-19 associated pneumonia in } \\
\text { clinical studies }\end{array}$ & Gao J. et al. & BioScience Trends & 130 \\
\hline 22 & Presumed Asymptomatic Carrier Transmission of COVID-19 & Bai Y. et al. & $\begin{array}{l}\text { JAMA-Journal of the } \\
\text { American Medical } \\
\text { Association }\end{array}$ & 123 \\
\hline 23 & $\begin{array}{l}\text { Receptor recognition by the novel coronavirus from Wuhan: } \\
\text { An analysis based on decade-long structural studies of SARS } \\
\text { coronavirus }\end{array}$ & Wan Y. et al. & Journal of Virology & 121 \\
\hline 24 & $\begin{array}{l}\text { A Trial of Lopinavir-Ritonavir in Adults Hospitalized with } \\
\text { Severe Covid-19 }\end{array}$ & Cao B. et al. & $\begin{array}{l}\text { The New England } \\
\text { journal of medicine }\end{array}$ & 119 \\
\hline 25 & CT imaging features of 2019 novel coronavirus (2019-NCoV) & Chung M. et al. & Radiology & 112 \\
\hline 26 & $\begin{array}{l}\text { Risk Factors Associated with Acute Respiratory Distress } \\
\text { Syndrome and Death in Patients with Coronavirus Disease } \\
2019 \text { Pneumonia in Wuhan, China }\end{array}$ & Wu C. et al. & $\begin{array}{l}\text { JAMA Internal } \\
\text { Medicine }\end{array}$ & 107 \\
\hline 27 & $\begin{array}{l}\text { Severe acute respiratory syndrome coronavirus } 2 \text { (SARS- } \\
\text { CoV-2) and coronavirus disease-2019 (COVID-19): The } \\
\text { epidemic and the challenges }\end{array}$ & Lai C.-C. et al. & $\begin{array}{l}\text { International Journal } \\
\text { of Antimicrobial } \\
\text { Agents }\end{array}$ & 104 \\
\hline 28 & $\begin{array}{l}\text { Clinical evidence does not support corticosteroid treatment for } \\
\text { 2019-nCoV lung injury }\end{array}$ & Russell C.D. et al. & The Lancet & 104 \\
\hline 29 & $\begin{array}{l}\text { Evolution of the novel coronavirus from the ongoing Wuhan } \\
\text { outbreak and modeling of its spike protein for risk of human } \\
\text { transmission }\end{array}$ & Xu X. et al. & $\begin{array}{l}\text { Science China Life } \\
\text { Sciences }\end{array}$ & 99 \\
\hline 30 & $\begin{array}{l}\text { Importation and human-to-human transmission of a novel } \\
\text { coronavirus in Vietnam }\end{array}$ & Phan L.T. et al. & $\begin{array}{l}\text { New England Journal } \\
\text { of Medicine }\end{array}$ & 98 \\
\hline 31 & $\begin{array}{l}\text { Genomic characterization of the } 2019 \text { novel human-pathogenic } \\
\text { coronavirus isolated from a patient with atypical pneumonia } \\
\text { after visiting Wuhan }\end{array}$ & Chan J.F.-W. et al. & $\begin{array}{l}\text { Emerging Microbes } \\
\text { and Infections }\end{array}$ & 92 \\
\hline 32 & $\begin{array}{l}\text { Radiological findings from } 81 \text { patients with COVID-19 } \\
\text { pneumonia in Wuhan, China: a descriptive study }\end{array}$ & Shi H. et al. & $\begin{array}{l}\text { The Lancet Infectious } \\
\text { Diseases }\end{array}$ & 90 \\
\hline 33 & $\begin{array}{l}\text { Time Course of Lung Changes On Chest CT During Recovery } \\
\text { From } 2019 \text { Novel Coronavirus (COVID-19) Pneumonia }\end{array}$ & Pan F. et al. & Radiology & 90 \\
\hline
\end{tabular}


Table 1. The Top 100 Most Cited COVID-19 Articles (Continued)

\begin{tabular}{|c|c|c|c|c|}
\hline \multicolumn{5}{|c|}{ The Top 100 Most-Cited Articles For COVID-19 } \\
\hline Rank & Title & Authors & Source title & $\begin{array}{c}\text { Total } \\
\text { Citations } \\
\end{array}$ \\
\hline 34 & $\begin{array}{l}\text { Emerging coronaviruses: Genome structure, replication, and } \\
\text { pathogenesis }\end{array}$ & Chen Y. et al. & $\begin{array}{l}\text { Journal of Medical } \\
\text { Virology }\end{array}$ & 89 \\
\hline 35 & $\begin{array}{l}\text { Persistence of coronaviruses on inanimate surfaces and their } \\
\text { inactivation with biocidal agents }\end{array}$ & Kampf G. et al. & $\begin{array}{l}\text { Journal of Hospital } \\
\text { Infection }\end{array}$ & 87 \\
\hline 36 & $\begin{array}{l}\text { Clinical characteristics of } 140 \text { patients infected with SARS- } \\
\text { CoV-2 in Wuhan, China }\end{array}$ & Zhang J.-J. et al. & $\begin{array}{l}\text { Allergy: European } \\
\text { Journal of Allergy and } \\
\text { Clinical Immunology }\end{array}$ & 84 \\
\hline 37 & $\begin{array}{l}\text { A novel coronavirus emerging in China-Key questions for } \\
\text { impact assessment }\end{array}$ & Munster V.J. et al. & $\begin{array}{l}\text { New England Journal } \\
\text { of Medicine }\end{array}$ & 81 \\
\hline 38 & $\begin{array}{l}\text { COVID-19: consider cytokine storm syndromes and } \\
\text { immunosuppression }\end{array}$ & Mehta P. et al. & The Lancet & 79 \\
\hline 39 & COVID-19 and Italy: what next? & Remuzzi A. et al. & The Lancet & 78 \\
\hline 40 & $\begin{array}{l}\text { Are patients with hypertension and diabetes mellitus at } \\
\text { increased risk for COVID-19 infection? }\end{array}$ & Fang L. et al. & $\begin{array}{l}\text { The Lancet } \\
\text { Respiratory Medicine }\end{array}$ & 77 \\
\hline 41 & $\begin{array}{l}\text { Cross-species transmission of the newly identified coronavirus } \\
\text { 2019-nCoV }\end{array}$ & Ji W. et al. & $\begin{array}{l}\text { Journal of Medical } \\
\text { Virology }\end{array}$ & 70 \\
\hline 42 & $\begin{array}{l}\text { Clinical predictors of mortality due to COVID-19 based on an } \\
\text { analysis of data of } 150 \text { patients from Wuhan, China }\end{array}$ & Ruan Q. et al. & $\begin{array}{l}\text { Intensive Care } \\
\text { Medicine }\end{array}$ & 70 \\
\hline 43 & $\begin{array}{l}\text { The Incubation Period of Coronavirus Disease } 2019 \\
\text { (COVID-19) From Publicly Reported Confirmed Cases: } \\
\text { Estimation and Application }\end{array}$ & Lauer S.A. et al. & $\begin{array}{l}\text { Annals of internal } \\
\text { medicine }\end{array}$ & 69 \\
\hline 44 & $\begin{array}{l}\text { A rapid advice guideline for the diagnosis and treatment of } \\
2019 \text { novel coronavirus (2019-nCoV) infected pneumonia } \\
\text { (standard version) }\end{array}$ & Jin Y.-H. et al. & $\begin{array}{l}\text { Military Medical } \\
\text { Research }\end{array}$ & 68 \\
\hline 45 & $\begin{array}{l}\text { Updated understanding of the outbreak of } 2019 \text { novel } \\
\text { coronavirus (2019-nCoV) in Wuhan, China }\end{array}$ & Wang W. et al. & $\begin{array}{l}\text { Journal of Medical } \\
\text { Virology }\end{array}$ & 67 \\
\hline 46 & $\begin{array}{l}\text { Sensitivity of Chest CT for COVID-19: Comparison to } \\
\text { RT-PCR }\end{array}$ & Fang Y. et al. & Radiology & 65 \\
\hline 47 & $\begin{array}{l}\text { Drug treatment options for the 2019-new coronavirus } \\
(2019-\mathrm{nCoV})\end{array}$ & Lu H. & BioScience Trends & 65 \\
\hline 48 & $\begin{array}{l}\text { Practical recommendations for critical care and anesthesiology } \\
\text { teams caring for novel coronavirus (2019-nCoV) patients } \\
\text { [Directives concrètes à l'intention des équipes de soins } \\
\text { intensifs et d'anesthésiologie prenant soin de patients atteints } \\
\text { du coronavirus } 2019-\mathrm{nCoV} \text { ] }\end{array}$ & Wax R.S. et al. & $\begin{array}{l}\text { Canadian Journal of } \\
\text { Anesthesia }\end{array}$ & 63 \\
\hline 49 & $\begin{array}{l}\text { An interactive web-based dashboard to track COVID-19 in } \\
\text { real time }\end{array}$ & Dong E. et al. & $\begin{array}{l}\text { The Lancet Infectious } \\
\text { Diseases }\end{array}$ & 62 \\
\hline 50 & COVID-19 and the cardiovascular system & Zheng Y.-Y. et al. & $\begin{array}{l}\text { Nature Reviews } \\
\text { Cardiology }\end{array}$ & 61 \\
\hline 51 & $\begin{array}{l}\text { Molecular and serological investigation of } 2019-\mathrm{nCoV} \\
\text { infected patients: implication of multiple shedding routes }\end{array}$ & Zhang W. et al. & $\begin{array}{l}\text { Emerging Microbes } \\
\text { and Infections }\end{array}$ & 61 \\
\hline
\end{tabular}


Table 1. The Top 100 Most Cited COVID-19 Articles (Continued)

\begin{tabular}{|c|c|c|c|c|}
\hline \multicolumn{5}{|c|}{ The Top 100 Most-Cited Articles For COVID-19 } \\
\hline Rank & Title & Authors & Source title & $\begin{array}{c}\text { Total } \\
\text { Citations } \\
\end{array}$ \\
\hline 52 & $\begin{array}{l}\text { Chest CT Findings in Coronavirus Disease-19 (COVID-19): } \\
\text { Relationship to Duration of Infection }\end{array}$ & Bernheim A. et al. & Radiology & 60 \\
\hline 53 & $\begin{array}{l}\text { Case-Fatality Rate and Characteristics of Patients Dying in } \\
\text { Relation to COVID-19 in Italy }\end{array}$ & Onder G. et al. & $\begin{array}{l}\text { JAMA-Journal of the } \\
\text { American Medical } \\
\text { Association }\end{array}$ & 60 \\
\hline 54 & $\begin{array}{l}\text { Critical Care Utilization for the COVID-19 Outbreak in } \\
\text { Lombardy, Italy: Early Experience and Forecast during an } \\
\text { Emergency Response }\end{array}$ & Grasselli G. et al. & $\begin{array}{l}\text { JAMA-Journal of the } \\
\text { American Medical } \\
\text { Association }\end{array}$ & 60 \\
\hline 55 & $\begin{array}{l}\text { The reproductive number of COVID-19 is higher compared to } \\
\text { SARS coronavirus }\end{array}$ & Liu Y. et al. & $\begin{array}{l}\text { Journal of Travel } \\
\text { Medicine }\end{array}$ & 59 \\
\hline 56 & Virtually Perfect? Telemedicine for Covid-19 & Hollander J.E. et al. & $\begin{array}{l}\text { The New England } \\
\text { journal of medicine }\end{array}$ & 58 \\
\hline 57 & Return of the coronavirus: $2019-\mathrm{nCoV}$ & Gralinski L.E. et al. & Viruses & 57 \\
\hline 58 & $\begin{array}{l}\text { Incubation period of } 2019 \text { novel coronavirus }(2019-\mathrm{nCoV}) \\
\text { infections among travellers from Wuhan, China, } 2028 \text { January } \\
2020\end{array}$ & Backer J.A. et al. & Eurosurveillance & 56 \\
\hline 59 & $\begin{array}{l}\text { World Health Organization declares global emergency: A } \\
\text { review of the } 2019 \text { novel coronavirus (COVID-19) }\end{array}$ & Sohrabi C. et al. & $\begin{array}{l}\text { International Journal } \\
\text { of Surgery }\end{array}$ & 55 \\
\hline 60 & $\begin{array}{l}\text { Clinical and biochemical indexes from } 2019-\mathrm{nCoV} \text { infected } \\
\text { patients linked to viral loads and lung injury }\end{array}$ & Liu Y. et al. & $\begin{array}{l}\text { Science China Life } \\
\text { Sciences }\end{array}$ & 51 \\
\hline 61 & $\begin{array}{l}\text { CT imaging of the } 2019 \text { novel coronavirus (2019-NCoV) } \\
\text { pneumonia }\end{array}$ & Lei J. et al. & Radiology & 51 \\
\hline 62 & $\begin{array}{l}\text { The neuroinvasive potential of SARS-CoV2 may play a role in } \\
\text { the respiratory failure of COVID-19 patients }\end{array}$ & Li Y.-C. et al. & $\begin{array}{l}\text { Journal of Medical } \\
\text { Virology }\end{array}$ & 50 \\
\hline 63 & $\begin{array}{l}\text { Fair Allocation of Scarce Medical Resources in the Time of } \\
\text { Covid-19 }\end{array}$ & Emanuel E.J. et al. & $\begin{array}{l}\text { The New England } \\
\text { journal of medicine }\end{array}$ & 50 \\
\hline 64 & $\begin{array}{l}\text { Dysregulation of immune response in patients with COVID-19 } \\
\text { in Wuhan, China }\end{array}$ & Qin C. et al. & $\begin{array}{l}\text { Clinical infectious } \\
\text { diseases: an official } \\
\text { publication of the } \\
\text { Infectious Diseases } \\
\text { Society of America }\end{array}$ & 50 \\
\hline 65 & $\begin{array}{l}\text { Coronavirus Disease } 2019 \text { (COVID-19): A Perspective from } \\
\text { China }\end{array}$ & Zu Z.Y. et al. & Radiology & 49 \\
\hline 66 & $\begin{array}{l}\text { Pattern of early human-to-human transmission of Wuhan } 2019 \\
\text { novel coronavirus (2019-nCoV), December } 2019 \text { to January } \\
2020\end{array}$ & Riou J. et al. & Eurosurveillance & 49 \\
\hline 67 & $\begin{array}{l}\text { Chloroquine and hydroxychloroquine as available weapons to } \\
\text { fight COVID-19 }\end{array}$ & Colson P. et al. & $\begin{array}{l}\text { International Journal of } \\
\text { Antimicrobial Agents }\end{array}$ & 46 \\
\hline 68 & $\begin{array}{l}\text { Feasibility of controlling COVID-19 outbreaks by isolation of } \\
\text { cases and contacts }\end{array}$ & Hellewell J. et al. & $\begin{array}{l}\text { The Lancet Global } \\
\text { Health }\end{array}$ & 46 \\
\hline 69 & Emerging 2019 novel coronavirus (2019-NCoV) pneumonia & Song F. et al. & Radiology & 46 \\
\hline
\end{tabular}


Table 1. The Top 100 Most Cited COVID-19 Articles (Continued)

\begin{tabular}{|c|c|c|c|c|}
\hline \multicolumn{5}{|c|}{ The Top 100 Most-Cited Articles For COVID-19 } \\
\hline $\begin{array}{l}\text { Rank } \\
\#\end{array}$ & Title & Authors & Source title & $\begin{array}{c}\text { Total } \\
\text { Citations }\end{array}$ \\
\hline 70 & $\begin{array}{l}\text { Structural basis for the recognition of SARS-CoV-2 by } \\
\text { full-length human ACE2 }\end{array}$ & Yan R. et al. & Science & 44 \\
\hline 71 & $\begin{array}{l}\text { The epidemiology and pathogenesis of coronavirus disease } \\
\text { (COVID-19) outbreak }\end{array}$ & Rothan H.A. et al. & $\begin{array}{l}\text { Journal of } \\
\text { Autoimmunity }\end{array}$ & 43 \\
\hline 72 & $\begin{array}{l}\text { Functional assessment of cell entry and receptor usage for } \\
\text { SARS-CoV-2 and other lineage B betacoronaviruses }\end{array}$ & Letko M. et al. & Nature Microbiology & 42 \\
\hline 73 & $\begin{array}{l}\text { Therapeutic options for the } 2019 \text { novel coronavirus } \\
(2019-\mathrm{nCoV})\end{array}$ & Li G. et al. & $\begin{array}{l}\text { Nature reviews. Drug } \\
\text { discovery }\end{array}$ & 42 \\
\hline 74 & $\begin{array}{l}\text { Chest CT findings in } 2019 \text { novel coronavirus (2019-NCoV) } \\
\text { infections from Wuhan, China: Key points for the radiologist }\end{array}$ & Kanne J.P. & Radiology & 42 \\
\hline 75 & $\begin{array}{l}\text { High expression of ACE2 receptor of } 2019-\mathrm{nCoV} \text { on the } \\
\text { epithelial cells of oral mucosa }\end{array}$ & $\mathrm{Xu} \mathrm{H}$. et al. & $\begin{array}{l}\text { International Journal } \\
\text { of Oral Science }\end{array}$ & 40 \\
\hline 76 & $\begin{array}{l}\text { How will country-based mitigation measures influence the } \\
\text { course of the COVID-19 epidemic? }\end{array}$ & Anderson R.M. et al. & The Lancet & 40 \\
\hline 77 & Covid-19-Navigating the uncharted & Fauci A.S. et al. & $\begin{array}{l}\text { New England Journal } \\
\text { of Medicine }\end{array}$ & 39 \\
\hline 78 & $\begin{array}{l}\text { The origin, transmission and clinical therapies on coronavirus } \\
\text { disease } 2019 \text { (COVID-19) outbreak-An update on the status }\end{array}$ & Guo Y.-R. et al. & $\begin{array}{l}\text { Military Medical } \\
\text { Research }\end{array}$ & 39 \\
\hline 79 & $\begin{array}{l}\text { Pulmonary Pathology of Early-Phase } 2019 \text { Novel Coronavirus } \\
\text { (COVID-19) Pneumonia in Two Patients With Lung Cancer }\end{array}$ & Tian S. et al. & $\begin{array}{l}\text { Journal of Thoracic } \\
\text { Oncology }\end{array}$ & 38 \\
\hline 80 & Coronavirus Disease 2019 (COVID-19) in Italy & Livingston E. et al. & JAMA & 38 \\
\hline 81 & COVID-19: what is next for public health? & Heymann D.L. et al. & The Lancet & 38 \\
\hline 82 & Defining the epidemiology of Covid-19-Studies needed & Lipsitch M. et al. & $\begin{array}{l}\text { New England Journal } \\
\text { of Medicine }\end{array}$ & 37 \\
\hline 83 & $\begin{array}{l}\text { Factors Associated With Mental Health Outcomes Among } \\
\text { Health Care Workers Exposed to Coronavirus Disease } 2019\end{array}$ & Lai J. et al. & JAMA network open & 37 \\
\hline 84 & $\begin{array}{l}\text { Case of the index patient who caused tertiary transmission } \\
\text { of coronavirus disease } 2019 \text { in Korea: The application of } \\
\text { lopinavir/ritonavir for the treatment of COVID-19 pneumonia } \\
\text { monitored by quantitative RT-PCR }\end{array}$ & Lim J. et al. & $\begin{array}{l}\text { Journal of Korean } \\
\text { Medical Science }\end{array}$ & 37 \\
\hline 85 & $\begin{array}{l}\text { Angiotensin receptor blockers as tentative SARS-CoV-2 } \\
\text { therapeutics }\end{array}$ & Gurwitz D. & $\begin{array}{l}\text { Drug Development } \\
\text { Research }\end{array}$ & 37 \\
\hline 86 & $\begin{array}{l}\text { Prevalence of comorbidities and its effects in coronavirus } \\
\text { disease } 2019 \text { patients: A systematic review and meta-analysis }\end{array}$ & Yang J. et al. & $\begin{array}{l}\text { International Journal } \\
\text { of Infectious Diseases }\end{array}$ & 36 \\
\hline 87 & Convalescent plasma as a potential therapy for COVID-19 & Chen L. et al. & $\begin{array}{l}\text { The Lancet Infectious } \\
\text { Diseases }\end{array}$ & 36 \\
\hline 88 & $\begin{array}{l}\text { Characteristics and Outcomes of } 21 \text { Critically Ill Patients with } \\
\text { COVID-19 in Washington State }\end{array}$ & Arentz M. et al. & $\begin{array}{l}\text { JAMA-Journal of the } \\
\text { American Medical } \\
\text { Association }\end{array}$ & 36 \\
\hline
\end{tabular}


Table 1. The Top 100 Most Cited COVID-19 Articles (Continued)

\begin{tabular}{|c|c|c|c|c|}
\hline \multicolumn{5}{|c|}{ The Top 100 Most-Cited Articles For COVID-19 } \\
\hline $\begin{array}{l}\text { Rank } \\
\#\end{array}$ & Title & Authors & Source title & $\begin{array}{c}\text { Total } \\
\text { Citations }\end{array}$ \\
\hline 89 & $\begin{array}{l}\text { Potent binding of } 2019 \text { novel coronavirus spike protein by a } \\
\text { SARS coronavirus-specific human monoclonal antibody }\end{array}$ & Tian X. et al. & $\begin{array}{l}\text { Emerging Microbes } \\
\text { and Infections }\end{array}$ & 36 \\
\hline 90 & $\begin{array}{l}\text { Positive RT-PCR Test Results in Patients Recovered from } \\
\text { COVID-19 }\end{array}$ & Lan L. et al. & $\begin{array}{l}\text { JAMA-Journal of the } \\
\text { American Medical } \\
\text { Association }\end{array}$ & 35 \\
\hline 91 & $\begin{array}{l}\text { Enteric involvement of coronaviruses: is faecal-oral } \\
\text { transmission of SARS-CoV-2 possible? }\end{array}$ & Yeo C. et al. & $\begin{array}{l}\text { The Lancet } \\
\text { Gastroenterology and } \\
\text { Hepatology }\end{array}$ & 35 \\
\hline 92 & $\begin{array}{l}\text { Online mental health services in China during the COVID-19 } \\
\text { outbreak }\end{array}$ & Liu S. et al. & $\begin{array}{l}\text { The Lancet } \\
\text { Psychiatry }\end{array}$ & 34 \\
\hline 93 & $\begin{array}{l}\text { Pathogenicity and transmissibility of } 2019-\mathrm{nCoV}-\mathrm{A} \text { quick } \\
\text { overview and comparison with other emerging viruses }\end{array}$ & Chen J. & $\begin{array}{l}\text { Microbes and } \\
\text { Infection }\end{array}$ & 34 \\
\hline 94 & The COVID-19 epidemic & Velavan T.P. et al. & $\begin{array}{l}\text { Tropical Medicine and } \\
\text { International Health }\end{array}$ & 34 \\
\hline 95 & $\begin{array}{l}\text { Prevalence and impact of cardiovascular metabolic diseases on } \\
\text { COVID-19 in China }\end{array}$ & Li B. et al. & $\begin{array}{l}\text { Clinical Research in } \\
\text { Cardiology }\end{array}$ & 33 \\
\hline 96 & $\begin{array}{l}\text { Estimating the asymptomatic proportion of coronavirus } \\
\text { disease } 2019 \text { (COVID-19) cases on board the Diamond } \\
\text { Princess cruise ship, Yokohama, Japan, } 2020\end{array}$ & Mizumoto K. et al. & Eurosurveillance & 33 \\
\hline 97 & $\begin{array}{l}\text { Immediate psychological responses and associated factors } \\
\text { during the initial stage of the } 2019 \text { coronavirus disease } \\
\text { (COVID-19) epidemic among the general population in China }\end{array}$ & Wang C. et al. & $\begin{array}{l}\text { International Journal } \\
\text { of Environmental } \\
\text { Research and Public } \\
\text { Health }\end{array}$ & 33 \\
\hline 98 & $\begin{array}{l}\text { The SARS, MERS and novel coronavirus (COVID-19) } \\
\text { epidemics, the newest and biggest global health threats: what } \\
\text { lessons have we learned? }\end{array}$ & Peeri N.C. et al. & $\begin{array}{l}\text { International journal } \\
\text { of epidemiology }\end{array}$ & 33 \\
\hline 99 & $\begin{array}{l}\text { COVID-19: Gastrointestinal Manifestations and Potential } \\
\text { Fecal-Oral Transmission }\end{array}$ & Gu J. et al. & Gastroenterology & 32 \\
\hline 100 & $\begin{array}{l}\text { Mental health care for medical staff in China during the } \\
\text { COVID-19 outbreak }\end{array}$ & Chen Q. et al. & $\begin{array}{l}\text { The Lancet } \\
\text { Psychiatry }\end{array}$ & 32 \\
\hline
\end{tabular}

landscape. Although the knowledge about COVID-19 is rapidly expanding and changing, this study offers important quantitative information to understand the current progress and trends of COVID-19 research. Furthermore, the most prolific authors and countries were identified to encourage inter-country collaboration among the top active researchers found in this study. The top 100 articles were published in 50 different journals, reflecting the multidisciplinary nature and complexity of this disease. To our knowledge, this is the first bibliometric analysis on COVID-19. The results of our study showed that COVID-19 research is unprecedented with more than 6500 publications in under a year. Moreover, the top cited COVID-19 articles are important for future researchers to consider. This study will serve as a reference for COVID-19 research and an educational foundation for physicians and researchers. 


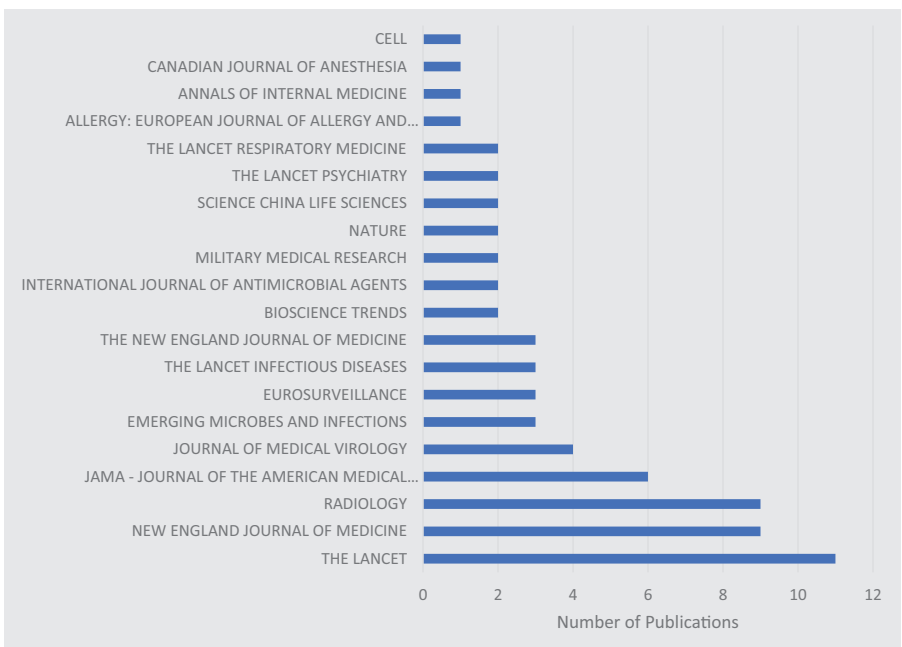

Figure 2. Top 20 journals.

Article citation: Johnson TD, Sakya SM, Sakya JP, Onkendi E, Hallan DR. The top 100 most cited articles on COVID-19. The Southwest Respiratory and Critical Care Chronicles 2020;8(35):42-50

From: The School of Medicine (TDJ, SMS), Penn State University College of Medicine, Hershey, PA; Department of Surgery (EO), Texas Tech University Health Sciences Center, Lubbock, TX; Department of Neurosurgery (DRH), Penn State University College of Medicine, Hershey, PA; School of Medicine (JPS), Texas Tech University Health Sciences Center, Lubbock, Texas

Submitted: $6 / 22 / 2020$

Accepted: $7 / 13 / 2020$

Reviewer: Gilbert Berdine MD

Conflicts of interest: none

This work is licensed under a Creative Commons

Attribution-ShareAlike 4.0 International License.

\section{REFERENCES}

1. Aria M, Cuccurullo C. Bibliometrix: An R-tool for comprehensive science mapping analysis. J Informetr 2017;11(4): 959-975.

2. Huang C, Wang Y, Li X, et al. Clinical features of patients infected with 2019 novel coronavirus in Wuhan, China. Lancet 2020 Jan 30;395(10223):497-506.

3. Sohrabi C, Alsafi Z, O'Neill N, et al. World Health Organization declares global emergency: A review of the 2019 novel coronavirus (COVID-19). Int J Surg 2020 Apr;76:71-76.

4. Singhal T. A review of coronavirus disease-2019 (COVID19). Indian J Pediatr 2020 Apr;87(4):281-286.

5. Dong E, Du H, Gardner L. An interactive web-based dashboard to track COVID-19 in real time. Lancet Infect Dis; c2020 [cited 2020 May 15]. Available from: https://coronavirus.jhu. edu/us-map

6. Mohammed MF, Marais O, Qureshi AI, et al. The top 100 most cited articles in stroke imaging: a bibliometric analysis. Curr Probl Diagn Radiol 2018 May-Jun;47(3):161-167. 